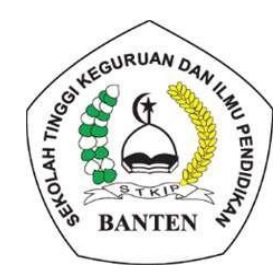

\title{
UPAYA MENINGKATKAN HASIL BELAJAR PADA ANAK USIA DINI DI TAMAN KANAK-KANAK AZ-ZAHRA LEWAT METODE DISKUSI KELOMPOK
}

\author{
Alvan Hazhari \\ Sekolah Tinggi Keguruan dan Ilmu Pendidikan Banten \\ hazharialvan2193@gmail.com \\ Artikel : \\ Metode Diskusi Kelompok untuk Meningkatkan Hasil Belajar \\ Penerima: Juli $2021 \quad$ Diterima: Agustus $2021 \quad$ Dipublikasikan: September 2021
}

\begin{abstract}
Based on the results of observations made at the Az-Zahra Kindergarten (TK) with a total of 35 children, several weaknesses were found that affect children's learning outcomes and also the children's response to lessons on the "Animals" theme was less than optimal. In response to these problems, it is necessary to develop a learning method used with the group discussion method as an alternative that makes learning more effective as expected and is able to improve the child's own learning outcomes. This research was conducted using an approach approach, the design used was Classroom Action Research (CAR) which consisted of two cycles which in its implementation went through several stages, namely planning, action, observation, and reflection. The subjects of this study were Az-Zahra Kindergarten class B children consisting of 19 children consisting of 6 boys and 29 girls. The results of this study obtained the following data: Cycle I carried out two meetings with children, the results of the first cycle obtained a percentage value of learning completeness of $46 \%$ of the total number of children, namely 35 children with an average value of 72 , while in the second cycle there were two meetings and obtained the percentage value of learning completeness of $88 \%$ with an average value of 83 and has reached the predetermined KKM value of 75. From these observations it can be concluded that the use of group learning methods is declared quite successful in the implementation of teaching and learning activities with The theme is "Animals" and can be recommended as an effective learning method for students, especially in Az-Zahra Kindergarten.
\end{abstract}

Keywords: Group Discussion Learning Method, Learning Outcomes, Pets.

\begin{abstract}
ABSTRAK
Berdasarkan hasil observasi yang dilakukan di Taman Kanak-Kanak (TK) AzZahra dengan jumlah sebanyak 35 anak, ditemukan beberapa kelemahan yang mempengaruhi hasil belajar anak dan juga respon anak terhadap pelajaran pada Tema "Binatang Peliharaan" kurang optimal. Menyikapi masalah tersebut, perlu dikembangkan metode pembelajaran yang digunakan dengan metode diskusi kelompok sebagai salah satu alternatif yang menjadikan pembelajaran lebih efektif sesuai yang diharapkan dan mampu meningkatkan hasil belajar anak itu sendiri. Penelitian ini dilakukan dengan menggunakan pendekatan kualitatif, desain yang digunakan adalah Penelitian Tindakan
\end{abstract}


Kelas (PTK) yang terdiri dari dua siklus yang mana dalam pelaksanaannya melalui beberapa tahapan yaitu perencanaan, tindakan, observasi dan refleksi. Subjek dari penelitian ini yaitu anak Taman Kanak-Kanak Az-Zahra kelas B yang berjumlah 19 anak terdiri dari 6 anak laki-laki dan 29 anak perempuan. Hasil dari penelitian ini didapatkan data sebagai berikut: Siklus I dilaksanakan dua kali pertemuan dengan anak, hasil dari siklus I diperoleh nilai persentase ketuntasan belajar anak sebesar $46 \%$ dari jumlah seluruh anak yaitu 35 anak dengan nilai rata-rata 72, sedangkan pada siklus II dilaksanakan dua kali pertemuan dan diperoleh nilai persentase ketuntasan belajar sebesar 88\% dengan nilai rata-rata sebesar 83 dan sudah mencapai nilai KKM yang telah ditetapkan sebesar 75. Dari hasil observasi tersebut dapat ditarik kesimpulan bahwa penggunaan metode pembelajaran diskusi kelompok dinyatakan cukup berhasil dalam pelaksanaan kegiatan belajar mengajar dengan Tema "Binatang Peliharaan" dan dapat direkomendasikan sebagai metode pembelajaran yang efektif untuk siswa terutama di Taman Kanak-Kanak Az-Zahra.

Kata kunci : Metode Pembelajaran diskusi kelompok, Hasil Belajar, Binatang Peliharaan.

\section{PENDAHULUAN}

Pembentukan moral anak bangsa semakin merosot. Salah satu penyebabnya adalah kurang tertariknya dengan metode pembelajaran yang diberikan yang terkesan monoton sehingga siswa merasa bosan mengikuti kegiatan pembelajaran yang berpengaruh pada hasil belajar mereka. Hasil belajar adalah kemampuan dalam pengetahuan, sikap dan keterampilan yang diperoleh anak setelah menerima pelajaran yang diberikan oleh seseorang atau guru sehingga dapat mengaplikasikan hasil belajar atau kemampuannya dalam kehidupan sehari-hari sebagai warga negara yang baik.

Oleh karena itu untuk meningkatkan hasil belajar anak peneliti mencoba mengembangkan metode pembelajaran yang akan digunakan oleh peneliti yaitu menggunakan metode pembelajaran eksplorasi. Metode diskusi kelompok adalah anak disuruh menjelajahi atau mencari tahu sendiri apa yang disuruh lewat arahan peneliti atau guru lewat diskusi untuk menganalisis, memecahkan masalah, menggali atau memperdebatkan topik atau permasalahan tertentu.

Lewat Permasalahan tersebut maka peneliti mengangkat judul "Upaya Meningkatkan Hasil Belajar Pada Anak Usia Dini Di Taman Kanak-Kanak Az-Zahra Lewat Metode Diskusi Kelompok".

\section{LANDASAN TEORI}

\section{Pengertian Hasil Belajar}

Hasil belajar sering kali digunakan sebagai ukuran untuk mengetahui seberapa jauh seseorang menguasai bahan yang sudah diajarkan. Untuk mengaktualisasikan hasil belajar tersebut diperlukan serangkaian pengukuran menggunakan alat evaluasi yang baik dan memenuhi syarat. Pengukuran demikian dimungkinkan karena pegukuran merupakan kegiatan ilmiah yang dapat diterapkan pada berbagai bidang termasuk pendidikan. 
Hasil belajar adalah kemampuan-kemampuan yang dimiliki anak setelah ia menerima pengalaman belajarnya. Hasil belajar mencakup kemampuan kognitif, afektif dan psikomotorik. Yang harus diingat, hasil belajar adalah perubahan perilaku secara keseluruhan bukan hanya salah satu aspek potensi kemanusiaan saja. Artinya, hasil pembelajaran yang dikategorisasi oleh para pakar pendidikan sebagaimana tersebut diatas tidak dilihat secara fragmentaris atau terpisah, melainkan secara komprehensif atau secara luas. Metode Diskusi Kelompok.

\section{Hakikat Metode Diskusi Kelompok}

Metode adalah cara guru menyampaikan materi pelajaran kepada anak untuk mencapai tujuan tertentu

Metode pembelajaran adalah cara yang digunakan untuk menyampaikan pelajaran kepada anak. Karena penyampaian itu berlangsung dalam interaksi edukatif, metode pembelajaran dapat diartikan sebagai cara yang digunakan oleh guru dalam mengadakan hubungan dengan anak pada saat berlangsungnya pengajaran. Dengan demikian metode pembelajaran merupakan alat untuk menciptakan proses belajar mengajar.

Metode diskusi adalah interaksi antara anak dan anak, atau anak dengan guru untuk menganalisis, memecahkan masalah, menggali atau memperdebatkan topik atau permasalahan tertentu.

Sedangkan menurut Arends (1997) mendefinisikan diskusi dan diskursus sebagai komunikasi seseorang berbicara satu dengan yang lain, saling berbagi, gagasan dan pendapat.

Adapun menurut Suryosubroto (1997) diskusi adalah suatu percakapan ilmiah oleh beberapa orang yang tergabung dalam satu kelompok umtuk saling bertukar pendapat tentang suatu masalah, atau bersama-sama mencari pemecahan mendapatkan jawaban dan kebenaran atas suatu masalah.

Menurut Killen (1998), diskusi adalah metode pembelajaran yang menghadapkan siswa pada suatu permasalahan. Tujuan utama metode ini adalah untuk pemecahan suatu masalah, menjawab pertanyaan, menambah dan memahami pengetahuan anak, serta untuk membuat suatu keputusan. Oleh karena itu, diskusi bukanlah debat yang bersifat adu argumentasi. Diskusi lebih bersifat bertukar pengalaman untuk menentukan keputusan tertentu secara bersamasama.

\section{Tujuan Pembelajaran Diskusi Kelas}

Diskusi secara umum digunakan untuk memperbaiki cara berpikir dan keterampilan komunikasi anak dan untuk menggalakkan keterlibatan anak didalam pelajaran. Namun secara khusus menurut Tjokrodihardjo diskusi digunakan oleh para guru untuk setidaknya tiga tujuan pembelajaran yang penting.

\section{Kelebihan dan kelemahan metode diskusi kelompok \\ Kelebihan metode diskusi kelompok}


a. Metode diskusi dapat merangsang anak untuk lebih kreatif khusunya dalam meberikan gagasan dan ide-ide.

b. Dapat melatih untuk membiasakan diri bertukar pikiran dalam mengatasi setiap permasalahan.

Kelemahan metode diskusi kelompok

a. Sering terjadi pembicaraan dalam diskusi dikuasai oleh 2 atau 3 orang anak yang memiliki keterampilan berbicara.

b. Kadang-kadang pembahasan dalam diskusi meluas sehingga kesimpulan menjadi kabur.

\section{METODOLOGI PENELITIAN}

Metodologi penelitian yang digunakan pada penelitian dalam skripsi ini adalah metode PTK (Penelitian Tindakan Kelas). Penelitian Tindakan Kelas akan dilaksanakan di Taman KanakKanak Az-Zahra Kab. Serang Propinsi Banten. Subjek dalam penelitian ini adalah anak kelas B, yang berjumlah 35 orang/anak.

Tabel 3.1

Rencana Kegiatan Penelitian

\begin{tabular}{|c|c|c|c|c|c|c|c|c|}
\hline \multirow[b]{3}{*}{ No } & \multirow[b]{3}{*}{$\begin{array}{c}\text { Kegiat } \\
\text { an }\end{array}$} & \multicolumn{7}{|c|}{ Waktu } \\
\hline & & \multicolumn{4}{|c|}{ Bulan ke 1} & \multicolumn{3}{|c|}{ Bulan ke 2} \\
\hline & & 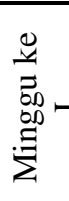 & $\stackrel{ \pm}{ \pm}$ & $\cong$ & $\stackrel{\mathscr{y}}{=}$ & 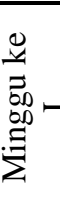 & 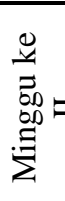 & 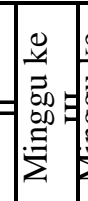 \\
\hline 1 & $\begin{array}{l}\text { Pra } \\
\text { Survey }\end{array}$ & $\sqrt{ }$ & & & & & & \\
\hline 2 & $\begin{array}{l}\text { Observ } \\
\text { asi }\end{array}$ & & $\sqrt{ }$ & $\sqrt{ }$ & & $\sqrt{ }$ & $\sqrt{ }$ & \\
\hline 3 & $\begin{array}{l}\text { Wawa } \\
\text { ncara }\end{array}$ & & & & $\sqrt{ }$ & & & $\sqrt{ }$ \\
\hline
\end{tabular}

(c) 2021, Tulip, Jurnal Tulisn Ilmiah Pendidikan. STKIPB e-ISSN: $2807-4114$

\section{Prosedur Penelitian Tindakan} Kelas

a. Menyusun (Planning)

Perencanaan

Pada tahap ini kegiatan yang harus dilakukan adalah membuat RPPH, mempersiapkan fasilitas dari sarana pendukung yang diperlukan dikelas, mempersiapkan instrumen untuk merekam dan menganalisis data mengenai proses dan hasil tindakan.

b. Melaksanakan Tindakan (Acting)

Pada tahap ini peneliti melakukan tindakan - tindakan yang telah dirumuskan dalam RPPH, dalam situasi yang actual, yang meliputi kegiatan awal, inti dan penutup.

c. Melaksanakan Pengamatan (Observing)

Pada tahap ini yang harus dilaksanakan adalah mengamati perilaku siswa - siswi yang sedang mengikuti kegiatan pembelajaran. Memantau kegiatan diskusi atau kerja sama antar kelompok mengamati pemahaman tiap - tiap siswa dalam penguasaan materi pembelajaran yang telah dirancang sesuai dengan PTK.
d. Melakukan
Refleksi (Reflecting)

Pada tahap ini yang harus dilakukan adalah mencatat hasil observasi, mengevaluasi hasil observasi, menganalisis hasil pembelajaran, mencatat kelemahan - kelemahan untuk dijadikan bahan penyusunan rancangan siklus berikutnya sampai tujuan PTK tercapai. 
Gambar 3.1

Prosedur Penelitian Tindakan Kelas (Kurt Lewin)

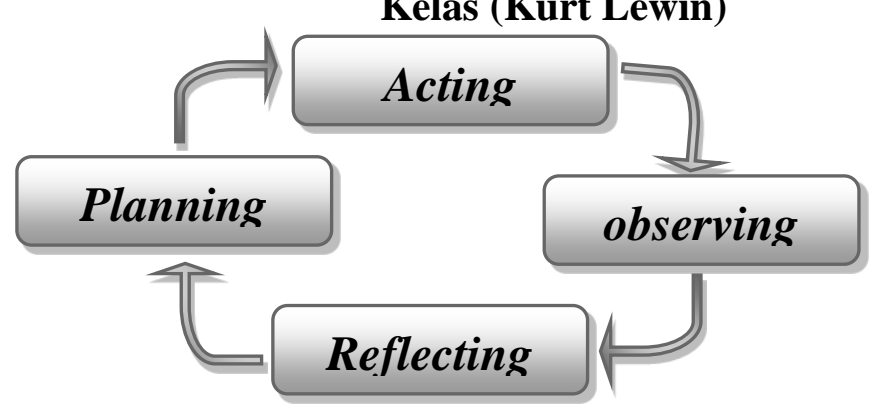

2. Teknik Pengumpulan Data

Teknik pengumpulan data yang akan digunakan yaitu berupa lembar tes tertulis yang akan diberikan kepada siswa, lembar observasi, lembar wawancara dan studi dokumen. Untuk lebih jelasnya berikut teknik pengumpulan data yang digunakan peneliti, seperti tertera dibawah ini :

a. Tes adalah sejumlah pertanyaan yang disampaikan kepada seseorang atau sejumlah orang untuk mengungkapkan keadaan atau tingkat perkembangan didalam dirinya.

b. Observasi yaitu dengan penelitian tindakan kelas ini yang bertindak sebagai observer yaitu peneliti sendiri yang akan dibantu oleh guru mata pelajaran yang ada disekolah.

c. Studi Dokumen yaitu teknik ini digunakan untuk mencari data mengenai hal - hal atau variabel yang berupa catatan, transkip, buku, agenda dan sebagainya. Dokumen yang digunakan untuk memperoleh data sekolah dan data identitas anak antara lain seperti nama anak, nomor induk anak, dengan melihat dokumentasi yang ada disekolah.

\section{Alat Pengumpulan Data}

Alat pengumpulan data adalah pedoman, alat atau teknik yang digunakan untuk memperoleh data selama melaksanakan penelitian. Alat yang digunakan dalam penelitian ini adalah butir soal, lembar observasi dan alat dokumentasi (kamera).

\subsection{Analisis Data}

Setelah data terkumpul, langkah berikutnya data tersebut dianalisis. Pengolahan dan analisis data ini dilakukan selama berlangsungnya penelitian sejak awal sampai akhir pelaksanaan tindakan. Jenis data yang didapat dalam peneltian ini yaitu data kualitatif dan data kuantitatif.

\section{HASIL DAN PEMBAHASAN PENELITIAN}

\section{Hasil Penelitian}

\section{SIKLUS I}

\section{Perencanaan}

Pada tahapan ini peneliti melaksanaan perencanaan yang berkaitan dengan langkah-langkah yang akan dilakukan dengan tindakan.

\section{Tindakan}

Pada tahapan ini guru dan peneliti melakukan proses pembelajaran yang sesuai dengan apa yang telah direncanakan sebelumnya. Pelaksanaan tindakan ini berguna untuk memperbaiki proses pembelajaran.

\section{Observasi}

Pada tahap ini peneliti mengamati anak pada proses pembelajaran berlangsung, kemudian hasil observasi akan dijadikan refleksi bagi tindakan yang telah 
dilakukan dan rencana tindakan selanjutnya.

Tabel 4.1

Ketuntasan belajar siswa

\begin{tabular}{|c|c|c|}
\hline Ketuntasan & \multicolumn{2}{|c|}{ Siklus I } \\
\cline { 2 - 3 } Siswa & $\sum$ siswa & \% \\
\hline Tuntas & $\mathbf{1 7}$ & $\mathbf{4 8} \%$ \\
\hline $\begin{array}{c}\text { Belum } \\
\text { Tuntas }\end{array}$ & $\mathbf{1 8}$ & $\mathbf{5 2} \%$ \\
\hline
\end{tabular}

Berdasarkan tabel 4.2 hasil tes formatif anak nilai rata-rata kelas digambarkan dalam bentuk grafik sebagai berikut :

Grafik 4.1

Nilai jumlah test formatif siswa siklus I

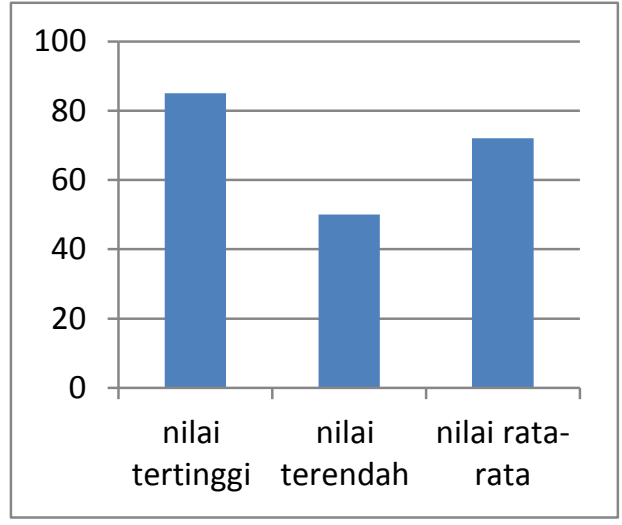

\section{Refleksi}

Dari hasil diskusi dengan guru atau peneliti pada pembelajaran yang telah dilakukan, terdapat hal-hal yang perlu diperbaiki dan ditingkatkan. Dan hal ini dapat dilihat dari hasil belajar anak nilai rata-rata kelas 73 belum mencapai nilai KKM yang ditetapkan sebesar 75, dikarenakan masih ada 52\% anak dari jumlah seluruh anak yang nilainya belum mencapai
KKM, maka dari itu penelitian ini perlu observasi lanjutan perbaikan dengan pelaksanaan siklus II.

\section{SIKLUS II}

\section{Perencanaan}

Bila dilihat pada hasil siklus I yang masih belum maksimal, maka pada siklus II yang akan dilaksanakan ini, dan dilakukan perencanaan pembelajaran antara peneliti dan guru kelas. Seperti pada siklus I, perencanaan pembelajaran pada siklus II ini pula akan menggunakan metode pembelajaran diskusi dengan format melalui tes formatif yang berupa lembar kerja anak. Dalam tahap ini peneliti merencanakan pembelajaran yang berkaitan dengan langkahlangkah yang akan dilakukan dalam tahap tindakan.

\section{Tindakan}

Pada tahapan ini guru atau peneliti melakukan proses pembelajaran yang sesuai dengan yang telah direncanakan sebelumnya. Pelaksanaan tindakan ini berguna untuk memperbaiki proses pembelajaran yang masih belum maksimal dalam hasil belajar pada siklus I.

\section{Observasi}

Pada tahap ini peneliti mengamati anak pada proses pembelajaran berlangsung, kemudian hasil observasi akan dijadikan refleksi bagi tindakan yang telah dilakukan dan rencana tindakan selanjutnya. 
Tabel 4.4 Ketuntasan belajar siswa

\begin{tabular}{|c|c|c|}
\hline Ketuntasan & \multicolumn{2}{|c|}{ Siklus II } \\
\cline { 2 - 3 } Siswa & $\sum$ siswa & $\%$ \\
\hline Tuntas & 31 & $\mathbf{8 8} \%$ \\
\hline $\begin{array}{c}\text { Tidak } \\
\text { Tuntas }\end{array}$ & 4 & $12 \%$ \\
\hline
\end{tabular}

Berdasarkan tabel 4.3 diatas, hasil tes formatif siswa nilai rata-rata kelas digambarkan dalam bentuk grafik terlihat seperti grafik dibawah ini :

Grafik 4.2

Nilai jumlah tes formatif siswa siklus II

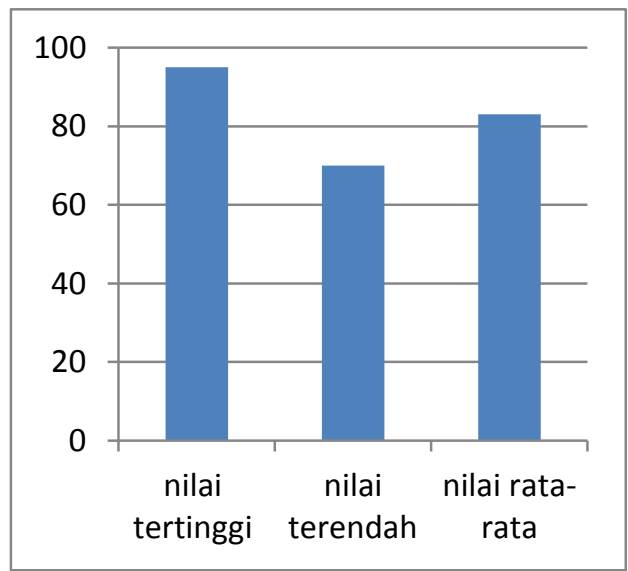

4. Refleksi

Berdasarkan hasil skor rata-rata kelas pada observasi siklus II diperoleh kesimpulan bahwa kegiatan perencanaan pembelajaran dan proses kegiatan belajar dengan menggunakan metode pembelajaran diskusi dikatakan "Berhasil" dan dapat direkomendasikan sebagai metode pembelajaran yang efektif untuk kegiatan pembelajaran pada mata pelajaran Pendidikan

Kewarganegaraan.

\section{KESIMPULAN DAN SARAN \\ Kesimpulan}

Penelitian ini dilakukan terhadap anak kelas B Taman Kanak-kanak Az-Zahra. Dari hasil analisis dan pembahasan hasil penelitian, dapat ditarik kesimpulan sebagai berikut :

1. Jumlah persentase keseluruhan hasil tes kemampuan representasi anak yang dilaksanakan dengan metode pembelajaran diskusi kelompok disiklus I mencapai nilai rata - rata kelas 73, dinyatakan masih dibawah KKM yang ditetapkan sebesar 75 . Sedangkan pada siklus II jumlah persentase mengalami kenaikan dari pada hasil tes siklus I, nilai rata-rata siklus II yaitu 83 dan telah mencapai KKM yangbtelah ditetapkan.

2. Berdasarkan hasil pengamatan yang sudah dilakukan, hasil belajar anak terlihat meningkat setelah diadakan PTK dengan menggunakan metode pembelajaran diskusi kelompok. Aktivitas guru atau peneliti dan amak serta hasil tes yang sudah dianalisa dapat disimpulkan bahwa metode pembelajaran diskusi memberikan dampak positif terhadap keberhasilan mengajar guru atau peneliti dan dinilai cukup efektif dalam meningkatkan kemampuan representasi pada Tema "Binatang Peliharaan".

\section{Saran}

1. Bagi anak khususnya kelas B Taman Kanak-Kanak Az-Zahra, 
selalu berupaya untuk berlatih mengembangkan kemampuan berpikir kritis, mengemukakan pendapat dan berdiskusi dengan teman sekelompok. Dan menerapkan apa yang telah dipelajari di sekolah dengan baik dan bertanggung jawab di kehidupan sehari - hari.

2. Bagi guru, khususnya guru kelas Taman Kanak-Kanak Az-Zahra untuk terus mengembangkan metode pembelajaran yang digunakan disekolah, agar anak dapat mengikuti dengan baik proses pembelajaran yang sedang berlangsung yang tentu akan berpengaruh pada aktivtias dan hasil belajar anak.

\section{DAFTAR PUSTAKA}

Bungin, Burhan. 2013. Metodologi Penelitian Sosial \& Ekonomi : Format-format Kuantitatif dan Kualitatif untuk Studi Sosiologi, Kebijakan Publik, Komunikasi, Manajemen, dan Pemasaran. Jakarta : Prenada Media Group

Hamdani. 2011. Strategi Belajar Mengajar. Bandung : Pustaka Setia

Hamid Darmadi. 2011. Metode Penelitian Pendidikan. Bandung : Alfabeta

Jumanta, Hamdayama. 2014. Model dan Metode Pembelajaran Kreatif dan Berkarakter. Bogor : Ghalia Indonesia

Majid, Abdul. 2015. Strategi Pembelajaran. Bandung : Remaja Rosdakarya
Masitoh \& Laskmi Dewi. 2009. Strategi Pembelajaran. Jakarta : direktorat Jenderal Pendidikan Islam

Mulyasa. 2009. Praktik Penelitian Tindakan Kelas. Bandung : Remaja Rosdakarya

Purwanto. 2014. Evaluasi Hasil Belajar. Yogyakarta : Pustaka Pelajar

Sagala, Syaiful. 2012. Konsep dan Makna Pembelajaran. Bandung : Alfabeta

Slameto. 2010. Belajar dan Faktor Faktor Yang Mempengaruhinya. Jakarta : Rineka Cipta

Solihatin, Etin. 2012. Strategi Pembelajaran PPKN. Jakarta : Bumi Aksara

Sugiyono. 2010. Metode Penelitian Pendidikan (Pendekatan Kuantitatif, Kualitatif dan $R \& D)$. Bandung : Alfabeta

Suprijono, Agus. 2011. Cooperative Learning : Teori dan Aplikasi PAIKEM. Jakarta : Pustaka Pelajar

Suyadi. 2013. Panduan Penelitian Tindakan Kelas. Jogjakarta : Diva Press

Trianto, Ibnu Badar Al Tabany. 2014. Mendesain Model Pembelajaran Inovatif, Progresif dan Kontekstual : Konsep, Landasan dan Implementasi pada Kurikulum 2013 (Kutikulum 
9|Alvan Hazhari, Upaya Meningkatkan Hasil Belajar Pada Anak Usia Dini Di Taman Kanak-Kanak Az-Zahra Lewat Metode Diskusi Kelompok

Tematik Integratif / TKI). Jakarta : Prenada Media 